\title{
Women Empowerment in Amish's The Ramchandra Series: A Dharmic
}

\section{Narrative}

\author{
D. Jayavelu* \\ Research Scholar, Indus University, Gujarat, India \& \\ Asst.Prof, Sanjivani College of Engineering, Maharastra, India \\ jayaveludamu@gmail.com
}

Mamta Pillai

Asst.Prof, Indus University, Gujarat, India

Mamtapillai.gd@indusuni.ac.in

DOI: http://doi.org/ 10.36892/ijlls.v3i1.507

\begin{tabular}{ll}
$\begin{array}{l}\text { Received: } \\
\text { 04/02/2021 }\end{array}$ & Abstract \\
\hline Accepted: & the portrayal of women in literary texts over the centuries has been stuck in \\
19/03/2021 & the same is considered unjustified. The canon of reformers in the literary \\
& world has started to interpret feminism from various perspectives. Women \\
& characters are reformulated and rethought by the new emerging authors and \\
Those authors reinforce a new dimension to the status and moral experience of \\
Ram, Sita, Raavan, & women which was largely criticized in the domain of traditional literature. \\
Amish, Gender & The present research, therefore, intends to elicit the narrative technique of \\
equality, Women & Amish's writings and his treatment of women characters in his novels. \\
empowerment, & Amish's women characters falsify the claims of traditional portrayal. The \\
Ramchandra Series & female protagonists of his novels highlight the punctuated identities of Indian \\
& women. They are strong, challenge traditional norms. In this regard Amish's \\
& the Ram Chandra Series is a mythical fiction based on mythology of \\
& Ramayana with a multilinear narrative. This paper is intended to provide a \\
brief and authentic exposition of status of women in India during the Vedic \\
times with reference to the women characters in Amish's the Ram Chandra \\
Series in every aspect of social order like education, philosophy, religion, \\
administration and warfare.
\end{tabular}

\section{INTRODUCTION}

Literature is the mirror of society; it not only depicts the society of the age but also acts as it brings social revolutions. Each age in Literature propagates and promotes a cultural change according to the taste and whims and fancies of people. The perception over individual rights, individual psyche and individual identity has undergone a tremendous change in the postmodern era. A sense of freedom to express one's point has more validity than to follow blind orthodox views. At the same time, it observes both the futility and fertility of the traditional systems of its own and conceives it as of reality. This freedom sets up a person's relationship with God a more intimate one.

The myths which portrayed God as a supernatural power have now altered and cogitated and appreciated the supernatural power as merely a reference note, a specimen or an illustration to lead one's life with more self-assurance. Taking guidelines from a myth, one connects it with the real world and its day-to-day problems. The idealistic world, more often, has its base from the references of past understanding and learning or what have been taught. 
In postmodern writings, a few authors attempted it with success. The retelling of myths is not a new one as so many great poets and scholars like Kamban, Krittivas, Balramdas, Tulsidas et al have reproduced the Great myth of India, the Ramayana, with their versions of understanding. Similar is the case with Mahabharata.

The contemporary retellings are found to be rebellious with artistic interventions. The traditional native literary and philosophical approach of these narratives has undergone a change of interventions which was deeply influenced by the writers of the time. The impact of these interventions is made due to the conflict between the age long tradition and culture with the forces of globalization. While the former considered characters as God, demi-god and devil configuration, the latter considered them as different shades of their psychic orders. As the corpus of writers of this specific genre is being expanded every now and then, it is high time to debate the issues involved in re-fabrication.

\section{AMISH'S NOVELS: A UNIVERSAL OUTLOOK ON HUMANITY}

Amish's novels are expressions of a cultural citation conceived out of past culture. Indeed, mythological events are used to blend with the present. Though postmodernism writings frequently reject religion; religious themes are still underwater themes. In Amish's writings, the theme with sufficient events and references of contemporary events triggers and immerses every reader to get convinced with the justification made or at least made them contemplate the solutions aspired to. The Dharma or Adharma concepts, the welfare of society, gender equality, love towards animals or civic rules and regulations have a universal outlook for general humanity.

Amish uses a progressive 'magic realism' style as his themes deal with contemporary issues. One of the issues is women empowerment and gender equality. The 21 st century women have acquired equal rights in all spheres of life, because of the constant efforts taken by many social reformers and by the modification that took place in literature. The role of literature in women empowerment in a gender biased society is unparalleled. This paper focuses on the representation of women empowerment in Amish's Ram Chandra Series. With the help of Mythic characters, Amish clearly describes the gender equality that prevailed in ancient India. In his work Immortal India he says,"Yes, most medieval interpretations of our epics tend to be patriarchal...... But if you study the versions of the epics, of our myths, from an earlier era, it would not be so out of the ordinary to find very strong women, and interpretations that are not patriarchal." (Tripathi, 2017, p.43).

Ram Chandra Series presents the status of women in the distant past, felt by contemporary ideals of feminism. While reading the writings of Amish, one can be driven to contemplate the existing conflict of 'law'- the Institutional Law and 'dharma'- Personal Dharma and the Hindu Religious Laws and Code. The Dharma can be interpreted by every individual according to one's conscience. The Hindu Dharma transfers the onus on every individual's conscience

\section{WOMEN IN THE RAMCHANDRA SERIES}

In the Ramachandra series Sita, Sunaina, Samichi, Manthara, Kaikeyi, Kaushalya, Sumithra, Urmila and Radhika are portrayed as the embodiment of power and valour. All these characters are presented as dexterous, independent, professional and powerful. They are embodiments of political equality, economic rights and social identity. Women characters of Amish's works have a sense of freedom and discretion and they move into a realm of their own freedom. They are the typical representation of Hindu pre-Vedic society.

What is noticeable and to be closely scrutinized is that the pattern not only applies to strong characters like Sita, but also to lesser known characters like that of Samichi, Roshini, Radhika and Manthara in the retellings. Their lives have not been shadowed by the men in their lives; they have not been suppressed to achieve their dreams and thoughts. Instead they 
achieved what they want to be. They are very clear about their skills and competency. They get spoken not about their culinary skills but about their war skills, discerning and decision making skills and knowledge in administrative and state affairs.

Amish has been subtle in his treatment of women and traces their lives through the various poignant touch points in this series. His characters are from all walks of life. For example, Sita is a great visionary. Her vision is for the enhancement of humanity and the society as a whole. Sunaina represents the bureaucratic, she was not the idle sort. She plans to restore Mithila to its old glory. Samchi is from the bourgeoisie. Manthara is a capitalist. Roshini is from pharmaceuticals. Vedavati is a spiritual leader and a philanthropist. Radhika is an emissary. Also, the Aspirant Kaikeyi, the balanced Kousalya and the innocent Urmila illustrate the unheard voice of womanhood. They had a mission in their life

\section{SITA: THE VISIONARY LEADER}

Amish draws a pattern of Sita's life as equal as to Ram's and Raavan's and made her an equal to them in wisdom and warfare. Sita is not born from a mother's womb which makes her 'ayonija'. Sunaina had found her amidst the fields, abandoned by the mother who gave birth to her, from the clutches of wolves that had surrounded a solitary vulture fighting to protect this little born. Thus she begins to grow to be a silent warrior from her birth. She is at war with her uncle Kushadhwaj, with the rogues of the street of Mithila, with the Asuras and for the values that her husband stood for. According to Vishwamitra, She is born with the mission of changing the course of the world from adharma into dharma. She is the next 'Vishnu'. She can change the destiny of the land. Her role is to redeem the world from adharma. Sita is groomed by Sunaina in every aspect of life. Though after marriage, she leaves for her husband's home, she never loses her identity. Menon, (2012), in 'Seeing like a Feminist', rightly says,

We need to recognize that this form of the family----nuclear, patriarchal and patrilineal (that is descent traced through males and property inherited through males)---is not natural, nor is it something that has always existed in all parts of India. A key feature of this form of marriage (Hindu form) is patrilineal virilocality, in which the woman has no rights in her natal home (the home into which she was born) and leaves it forever after marriage, moving to her husband's home, with limited rights as a wife (p.23).

Sita's vision is to make India once again a perfect one. She knew it had lost its high state. The peace has gone. According to her, it was 'A liberal and polite society. It was a haven for arts, culture, music, conversations, debates ... They not only practised but proudly celebrated non-violence. Both verbal and physical. It was a perfect society. Like heaven.' (Tripathi, 2017, p.61). Sita believed in Charvak Philosophy which propagates pragmatism. She has been thinking about a balanced society consisting of intellectuals, warriors, traders, and skilled workers. It can be a sort of today's aspiration of India's effort to establish itself and a self-reliant nation by implementing schemes like digital India, Skill India movement and Make in India initiative. And as a true visionary she is very keen that the scale should not be tipped against any section of the people. There should be a fair balance between all. The unbalance of the society is made when people do not have the liberty to live a life with their innate guna and attributes. And it can happen when a section of people is oppressed or dominated by others. To her, it can also happen when you're made to follow the occupation of your parents and clan, rather than what you may want to pursue. (Tripathi, 2017, p.81).

As Arishtanemi says, "she is too rebellious." Her views on the caste system are too rebellious against the existing system. She wanted the currently existing caste system should be destroyed as it determines one's caste by one's attributes, qualities and deeds. The present caste system became rigid and based on a group's financial and political influence, some caste became 'higher' and others 'lower'. She completely agreed, though she felt it was harsh 
and unrealistic, with Vishwamitra's view that children must be adopted by the state at the time of their birth. The state would feed, educate and nurture the in-born talents of these children. Then, at the age of fifteen, an examination would be conducted for them. Based on the result, appropriate castes would be allocated to them. Eventually, they would be adopted by the same caste. The children would not know their birth-parents, only their adoptive casteparents. It seemed to be unrealistic but a visionary leader must make the unrealistic a realistic one if it serves better for the society where they live in. Sita is such a visionary one. She says that One must be pragmatic when dealing with Indians. Laws must be enforced, yes. But this cannot be an end in itself. You may sometimes need to even misuse the law to achieve what you want. (Tripathi, 2017, p.184).

As a visionary leader, she knew a leader is not one who gives what the people want but gives them better than they imagined only then was an ideal society possible. She is too pragmatic and she realizes that the society starts hating its Vaishyas and assumes that they make money through cheating and profiteering. But to her, if they do not prosper, then society does not produce wealth. It leads to frustrated and unrest society. She worried a lot as even Brahmins are not given due respect in India. People do not listen to the learned and start hating the businessmen. They idealize only the Kshatriyas, the warriors and their "Battlehonour". It shows that the society started hatred for money, disdain for wisdom and love of violence.

A society may have freedom but in moderation. Too much freedom is a disaster. She preferred a perfect balance between the Masculine and the Feminine. As an aspirant of the welfare of the society, one's doesn't just have rights but also have duties to the society. As a true Vishnu, her vision is always focused on the betterment of the society. This clarity in thought springs from the education she received.

\section{SUNAINA: THE LEADER}

Amish's Sunaina is one of the central women characters highlights bravery and efficacy as a leader who helps to understand the power structures of women in his novels. She also represents how one can transcend the stereotypical image of ideal femininity and evolve as a liberated and emancipated woman as the play grows. Queen Sunaina sets the agenda for Mithila. Mother Sunaina sets the agenda for the life of Sita. She gives voice to the voiceless and challenges the patriarchal notions of feminine identity. In the old mythical narratives, women were seen from the androcentric perspective and were portrayed merely as puppets, unable to express their talents and capabilities. But, in Amish's discourse of revisionist mythmaking, he attempts to revise, reinterpret and reconstruct the age-old myth with a balanced perspective. At the same time, instead of challenging patriarchal notions, it tries to establish the right balance in the society. Amish's central women characters break the shackles of the gender stereotypes and empower themselves. Amish Tripathi in his work Immortal India says that one of the important reasons why women suffer is because of "the patriarchal prism to interpret our past and myths" (Tripathi, 2017, p.22)

The status of women at Vedic period is well depicted by Amish. For example, Amish's Sunaina has, in fact, ruled Mithila, though the real king is Janak. She is endowed with a fighting spirit. While King Janak spends more time in philosophy and its deliberations, Sunaina takes care of the kingdom and rules it successfully. She is determined to restore Mithila to its old glory. Her life also emphasizes the imagery of the elephant herd. Elephants follow the system of matriarchy. The example of elephants is juxtaposed with Sunaina life. She leads Mithila to its prosperity. She had initiated reforms on local tax collection. She devolved administration into the village level. It reduced the strain on the Mithila bureaucracy and improved efficiency. Later, the death of the female head elephant foretells the death of Sunaina, Realising her end, Sunaina instils hope in Sita and asks her to be responsible and take care of the kingdom after her. As a skilful administrator she has used the 
increased revenue from agriculture to improve the Mithila security and retrained the bureaucracy. Under King Janak rule much of the charity and subsidy were not exactly utilized by the poor. But Sunaina's administrative reforms channelizes everything. The charity reached the poor and needy properly. As an able ruler she understood the desperation of the poor. According to her, their desperation brings the best in a human being. Either the best or the worst, it brings out the superlative of the human beings. When it brings the best, the poor become noble. Instead, in case it brings the worst, they become angry. A great ruler must have the dharma or the responsibility of helping the poor become the best gradually. To her, "Not everyone has the spirit to keep their character strong when their stomachs are empty." (Tripathi, 2017, p.36).

Sunaina believed in being practical. She is the motivating spirit of Sita till her death. She told her not to run away from the problem but to confront and manage them. In other words, she was the prototype of Sita by leading a life of warriors. As a true leader loves her people more than she loves her own soul. Her spirit of advising her daughter and to see her as a futuristic leader.

\section{SAMICHI: A WRECKED Self}

Amish's Samichi represents the working class people. She is poor but brave, loyal, sincere in her duties and perfectionist. She saved Sita from the roughs. When the work is assigned to she is sincere and doing it without fault. She is not an ordinary woman. She hates the man at the core. She, as an able attendant, rises through the ranks to be chief of police of Mithila. After Sita's marriage, she becomes the prime minister of Mithila. Her braveness sometimes astonishes Sita too as she said what matters is not the weapon, but the woman who wields that weapon. Samichi wondered of common people's discontent about the rulers though much subsidy and policies were introduced to reform their lifestyle.

Samichi is rather a friend than an attendant to Sita. Sita shares her personal life too with Samichi though Samichi is not as open as Sita. She insisted Sita to send Ram back to Ayodhya and tried her best to make Ram not to attend swayamvar. According to her, Ram is like an earnest, conscientious school boy and there is not a trace of cynicism in him. It is really a shock to the readers when she helped Raavan to capture Sita in order to take revenge on the death of Khara. Even though she disliked men, she too had a secret love of Khara. Her love made her blind and she is forced to go against her true friend. Her dislike of men is out of her painful childhood memories. She is the victim of the flesh trade. She pleaded with Kumbhakarna to save her. When Zabibi alias Samichi is liberated from the cruel clutches of flesh traders, she never hesitates to stab her father and chooses the slow, painful death for him. As Raavan liberated her from the flesh trade, He becomes the Great Iraiva to her. She is an embodiment of a woman who is ripped by the cruelty of the society. She is the one who is oppressed by men, having a painful childhood. Even her secret love never gets fulfilled. She becomes the embodiment of failure of love from childhood till her end. Such frustration leads her to decide against her true friendship. Though she helped Raavan out of her loyalty, she insisted Akampana not to kill Sita. But throughout the series one can identify and appreciate Samichi's determination towards the perfection of the work assigned.

\section{VEDAVATI: A RELIGIOUS REPRESENTATIVE}

Vedavati represents the religious leadership in the Ram Chandra Series. The philosophy she propagates is quintessential Indian deliberations of Dharma. Though she has been worshipped as a demigod, she does not have any supernatural or divine power. Like her, there are more Kanyakumaries available across India. Kanyakumaries are the female children worshipped as Goddess before they attain puberty. She is the only character who influences Raavan. Because of her death, Raavan became the enemy of aryavarta. When he feels low in his spirit, either she or her thoughts guides, educates and directs him on the path of dharma. 
She is the spirit who brought out the goodness in him and instils self-realization in him. Because of her, Raavan started using his money for the welfare of the poor and society. She is the woman who turned a pirate into a philanthropist. Raavan wants to build a big hospital for Sapt Sindhu. Raavan is indomitable by anyone save Vedavati. Even Kumbhakarna was confused as his mighty brother could not muster up his courage to speak to Vedavati. "Bereft of his usual bravado, he just stood in hiding and stared at the object of his devotion" (Tripathi, 2019, p.145). According to Vedavati dharma has been reduced to just rituals. The people forget the reasons behind following the rituals. To her,

...In the field of dharma, intentions matter as much, if not more, than the act itself. But one thing is clear. Only if you put your duty above yourself do you even have a chance of attaining a life of dharma. Selfishness is the one thing that's guaranteed to take you away from it (Tripathi, 2019, pp.159160).

To Vedavati, Karma is most certainly transactional and one should not think much on what is good or bad. One should not focus on action but on Karma. At the same time, karma should not be the centre of life. One must discover one's Being, one's Swatatva, and live in consonance with what one is meant to be. She understands that Raavan's Swatatva is demanding him to be a hero and he wants to be an arya. He never wants to be treated as a Naga- a deformed. He wants to be noble. He wants the acceptance and respect of the aryas where he was initially, in his childhood, rejected. This secret longing of Raavan is well understood by Vedavati. She knows that he would never have peace until he was accepted by them as a hero. But when she was brutally murdered by Sukarman, Raavan becomes the villain to Aryas. The monster within him awakens and he wants to avenge the death of Vedavati as well as for the rejection of him. She is the motivating spirit who makes him work hard and smart. Only because of her, he becomes focused and disciplined. But after her death, the motivating spirit changed as a monster and none is there to control the monster. His rage becomes unbridled. His enormous abilities become a disastrous one. Whatever positive energy she inoculates to make him a protector of the land turns futile. When Vedavati is with Raavan, he felt connected to the Mahadev.

'Roar, noble Raavan,' said Vedavati. 'But roar in favour of dharma. Roar to protect the innocent, the poor, the needy. Be a true follower of the Mahadev. Be aggressive, but for the good of others. Be tough, but only to nurture the weak. Be fearsome, but only to fight for the virtuous. That is what Lord Rudra stood for. Follow the Lord's example.' (Tripathi, 2019, pp.176-177).

But Vedavati's death made Mahadev into Rudra- the version of destruction. Instead of roaring to shield those who need protection, Raavan starts to roar to frighten people. Even after her death Vedavati's finger-bone pendant that hung around his neck controls him whenever he becomes more emotional.

\section{MINOR CHARACTERS BUT POWERFUL DEPICTION}

Amish's Kaikeyi is a passionate, wilful woman. She shows her bravery when she accompanies Dashrath on the battlefield in Lanka. She saves the life of Dashrath at the critical condition of war. She is ambitious for herself. Though she has been the brightest woman, she has her share of frustrations. Yet frustrated Kaikeyi sought vicarious recognition through Bharat, her son. She aimed to realise her ambitions through him (Tripathi, 2015).

But Kaikeyi's weakness is well utilized by Manthara. When Manthara demands the death of Dhenuka, Initially she refuses. But when Manthara assures her to help Bharat to become King as well as given her the hundi - a document to honour the debt of a stated sum of money - worth the equivalent of more than ten years of Ayodhya's royal revenue, Kaikeyi can not resist. She is shrewd and strategic. She knows how to handle the pressure; be it in the battlefield or at the palace. She makes everything work for her and succeeds in her attempts. 
Amish's Roshini is Manthara's daughter. She is a real medical officer doing the service for the welfare of common people without expecting anything in return. Though born to a wealthy businesswomen, she never calculates profits out of her profession. The deformed structure of her mother might have induced her to take the noble profession. She ties rakhi for Ram and his brothers refusing even a gift from them in return believing that accepting the gift is expecting benefit in her pure brother- sister love. She does not accept anything in return except a promise of physical protection.(Tripathi, 2015, p.105). In her view, women are capable of doing the work of Brahmins, Vaishyas and Shudras: disseminating Knowledge, trading or performing physical labour. But they cannot perform the role of a Kshatriya as they don't have the physical strength and proclivity for violence. But, unfortunately, she becomes the victim to the violence against women. As she believed she could not fight against the strong men and lost her life. She strongly believes that nature has blessed the women with other attributes equal to men. She donates to many charitable causes, especially the education and health of children, considered the worthiest of all by the great law book, Maitreyi Smriti. She has devoted her life to the service of the people. She was a woman of impeccable character, a picture of grace and dignity. So, when she was brutally murdered by Dhenuka, everyone demanded retribution. But, Ram is not able to punish Dhenuka as he was underage and exempted on a legal technicality. To Ram, the law must not be broken. But Bharat breaks the law to do justice. To Bharat, it may be against the law, but it is just. A brute force can only be met with equal brute force. Her murder, parallel with Nirbhaya case, exposes the flaw in law's technicality

Amish's Manthara is quite different from the picture portrayed about her so far. Down the ages, the character of Manthara has been portrayed as an evil figure. As everyone worships Ram, more often she is termed as an evil cause of Ramayana. As a result of Manthara's influence Kakeyi asks the banishment of Ram from Ayodha for fourteen years from Dashrat. But, Amish's Manthara is a brilliant businesswoman. She is rich and powerful. She can finance the entire realm of Ayodhya. Amish portrayal of Manthara as a powerful businesswoman gives novelty in approaching the Myth. By promoting Manthara to such a high level, Amish balanced the importance of gender equality. Infact, instead of showing our aversion towards Manthara, one starts to pity over her condition and the stress she underwent after losing her beloved daughter Roshini who was brutally raped and murdered by Dhenuka. Even one can start supporting her when she takes efforts to influence and seeks the support of Kaikeyi to punish the cruel Dhenuka. She is too diplomatic by maintaining a cordial relation with the Kingdom of Ayodhya and Lanka simultaneously. She lost her mental balance after her daughter's death. She wooed Kaikeyi to punish Dhenuka. She offered huge money to Kaikeyi for it as well as assured her to help Bharat to become King by using her influence to get the support for it from the Business community. As well, she paid the executioners handsomely not to hold back on the brutality of the execution. The agony she has undergone can be understood as she said, 'Don't come back to this ugly world, my child; it has not been created for one as pure as you" (Tripathi, 2015, p.168).

Not only Sita, Samichi, Kaikeyi, Vedavati and Manthara but also the minor characters like Urmila, Kekasi, Kousalya, Shurpanakha, Sunaina, Radhika and Sumitra voice the unheard melodies of the oppressed muses. Here, in the Ram Chandra Series, Amish's never propagates the 'only women' concept but he recommends the 'woman also' concept. His series is neither androcentric nor gynocentric but it represents a striking balance between the two genders. One cannot find any gender discrimination in his writings. Instead one can slowly understand gender equality and its importance, the value of women and the need of their representation for a progressive society. 


\section{CONCLUSION}

Amish clearly brings out this balance through his women characters. He skilfully intertwines his recommendations on women's empowerment, the caste system, the reformation required in law, the tradition and value of ancient culture through his interpretations of Indian mythologies though it slightly varied from the traditional stories. In Amish's writings, women have equal rights and contribute strongly to the development of events. Women are shown as great warriors, Philanthropists, Philosophers, Religious leaders, skilful businesswomen and able administrators who were equal to men and took some difficult decisions in critical times. Through the revisiting of these mythical stories he revives the actual women's empowerment. The gender equality presented by him in his fictions are the reflection of the literary representations that upkeep the concept of women emancipation. Even the ancient mythical women have drastically been transformed as a symbol of liberation in the hands of Amish's revision of myth. At the same time, he has captured the quintessence of Indian women who are capable of anything. They are resolute and self-reliant. Every Indian woman has a little bit of Sita, Samichi, Manthara, Vedavati and Roshini within them. The more hardship a woman goes through in her life, the more she shows innate strength to endure and emerge.

\section{REFERENCES}

Altekar, A. S. (2016). The Position of Women in Hindu Civilization : From Prehistoric Times to the Present Day. In. Delhi: Motilal Banarsidass Publishers Private Ltd. (Reprinted from: 12th Reprint).

Deivasigamani, T. New Image of Women: A Comparison between the Heroines and Other Female Characters of Amish Tripathi and Jaishree Misra.

Devi, T. S. V., \& Srividhya, A. Reinventing Sati and Sita: A Study of Amish Tripathi's Central Women Characters from a Feminist Perspective.

Lavanya, S. Sita-“The Born Vishnu" in Amish Tripathi's Sita: Warrior of Mithila.

Menon, N. (2012). Seeing Like A Feminist. Penguin Books Limited.

Patel, P. G., \& Nimavat, D. (2020). " Sita" A Reading in the light of Feminism. Studies in Indian Place Names, 40(42), 422-427.

Swarup, R. (2000). Women in Islam. Voice of India.

Tripathi, A. (2015). Ram Scion of Ikshvaku. Westland ltd.

Tripathi, A. (2017a). Immortal India: Young Country, Timeless Civilisation. Westland Publications Ltd.

Tripathi, A. (2017b). Sita Warrior of Mithila. Westland Publications Ltd.

Tripathi, A. (2019). Raavan: Enemy of Aryavarta. Westland

Tripathi, A. R., Bhavna. (2020). Dharma: Decoding The epics for a meaningful life. Westland Publications Private Ltd.

\section{$\underline{\text { AUTHORS' BIO }}$}

*D.Jayavelu is currently employed by Sanjivani College of Engineering, Kopargaon, Maharastra, India as an Asst.Prof in Department of Engineering Science and Humanities. He is currently pursuing his Research in Amish Tripathi's Writing at Indus University, Gujarat, India. His ongoing research interest includes Indology and Indian Writing in English.

https://orcid.org/0000-0002-2261-9387. 
Dr.Mamta Pillai is is currently the Head of Department of Language, Indus Institute of Sciences Humanities \& Liberal Studies, Indus University, Ahmedabad, Gujarat, India.She has completed her research in English Language Teaching. She actively publishes in the areas of higher education, instructional technology and creative thinking. 